\title{
5. 重症頭部外傷の病態と治療
}

久留米大学医学部脳神経外科

徳富 孝志

外傷性脳損傷急性期に認められる脳低酸素/虚血状態が,二 次性脳損傷の進行や転帰悪化に強く影響することが知られて いる．早期脳虚血状態の主な原因としては，低血圧や頭蓋内 圧光進に伴う脳灌流圧低下，あるいは止血炎症反応に伴う脳 微小循環障害などがあげられる，脳血管ならびに代謝の自動 調節能が障害されている場合には，これらの影響はさらに強 く現れる。したがって，二次性脳損傷を最小限にとどめるた めの急性期治療の主眼は，呼吸・血圧の安定化と頭盖内圧コ ントロールによって脳灌流圧を正常に保ち，かつ脳血流と代 謝の不均衡状態を是正して脳代謝を維持することにある。日 本神経外傷学会編「重症頭部外傷治療・管理のガイドライン」 においても呼吸，血圧，頭蓋内圧の管理法と管理目標につい て重点的に述べられている。 しかし，こ机らの点についても なお異論は多く，また確たるエビデンスに基づくものはわず かしかない．日本神経外傷学会の「頭部外傷データバンク」 報告では，重症例の死亡率は $51 \% て ゙ ，$ 社会復帰できたのはわ ずかに $15 \%$ のであった，重症例の治療がいかに困難かを示 すものであるが，管理法や管理目標についても，さらに検証 を進めるべき多くの課題が残されている. 